\title{
KONSEP KETATANEGARAAN DALAM PENATAAN STRUKTUR ORGANISASI PERANGKAT DAERAH DI TINJAU DARI PRINSIP EFISIEN DAN EFEKTIF
}

\author{
Edi Sofwan \\ Fakultas Ekonomi Universitas Pamulang \\ E-mail: dosen01183@unpam.ac.id
}

\begin{abstract}
Abstrak
Otonomi daerah adalah amanat reformasi yang harus dilaksanakan sesuai dengan ketentuan undang-undang, dengan adanya otonomi pemerintah daerah berkesempatan untuk menyusun organisasi perangkat daerah. Dalam peraturan perundang-undangan pemerintahan berhak membuat penyusunan perangkat daerah dalam bentuk organisasi daerah untuk membentuk struktur pemerintahan agar menjadi pemerintahan yang baik. Organisasi perangkat daerah tersebut bermaksud untuk menyelenggarakan jalannya pemerintahan daerah yang memiliki misi serta peranan masing-masing sehingga mampu untuk bertanggung jawab terhadap kepala daerahnya. Dan pada kenyataannya banyak lembaga pemerintahan daerah yang mementingkan pendekatan secara struktural dibandingkan pendekatan fungsional, berangkat dari hal tersebut terdapat kekeliruan dan ada juga struktur organisasi daerah yang terlalu gemuk sehingga tugas dan fungsinya tidak efisien dan efektif. Pada penelitian ini menggunakan metode Yuridis normatif yaitu dengan menggunakan metode pendekatan undang-undang, hasil dari penelitian menyimpulkan bahwa Melalui pelaksanaan penataan kelembagaan organisasi Daerah tersebut harapannya adalah fungsi pemerintah daerah agar bisa lebih efektif dan efisien dalam rangka mewujudkan penyelenggaraan tata kepemerintahan yang baik (good governance).
\end{abstract}

Kata kunci: penataan organisasi; perangkat daerah; efesien dan efektif.

\begin{abstract}
Regional autonomy is the mandate of reform that must be carried out in accordance with the provisions of the law, with the autonomy of the regional government having the opportunity to form an organization of regional authorities. In the laws and regulations, the government has the right to make the preparation of regional apparatus in the form of regional organizations to form a government structure so that it becomes a good government. The regional apparatus organization intends to carry out the running of regional governments that have a mission and their respective
\end{abstract}


roles so that they are able to take responsibility for their regional heads. And in fact many local government institutions that are concerned with a structural approach rather than a functional approach, departing from this there are errors and there are also regional organizational structures that are too fat so that their tasks and functions are inefficient and ineffective. In this study use the normative juridical method that is by using the method of approach to the law, the results of the study conclude Through the implementation of the institutional arrangement of the regional organizations the hope is the function of local governments to be more effective and efficient in order to realize the implementation of good governance (good governance).

Keywords: organizational structuring; regional devices; efficient and effective.

\section{Pendahuluan}

Indonesia merupakan negara yang besar, harus dikelola dengan baik dan benar, agar Indonesia menjad Negara yang maju dan bermartabat. Sejak Indonesia merdeka banyak perubahan yang terjadi untuk membentuk konsep ketatanegaraan berkaitan dengan konsep sentralisasi dan desentralisasi yang diperdebatkan, perubahan tersebut sangat dinamis yaitu berkaitan dengan membentuk pemerintahan yang tersusun dua tingkat yaitu tingkat pemerintahan pusat dan pemerintahan daerah. ${ }^{1}$

Perkembangan yang terjadi dalam sejarah justru menjalankan sistem pemerintahan dengan mekanisme sentralistik, terlihat pada pemerintahan orde lama ataupun orde baru. Kesempatan melaksanakan desentralisasi seluas-luasnya dengan gagasan otonomi daerah tidak terwujud. Akan tetepi sesudah memasuki era reformasi di Tahun 1998 serta memasuki era peralihan sejak orde baru ke reformasi, keinginan dan aspirasi untuk menjalankan otonomi daerah/desentralisasi kembali menguat dan penuh rasa optimis. ${ }^{2}$

Otonomi daerah telah membawa harapan baru terhadap optimisme kebijakan daerah dalam mengurus dan mengatur kepentingan masyarakat antara hubungan pusat dan daerah. Selama ini masyarakat didaerah merasa dimarginalkan oleh keadaan yang memaksa karena tidak bisa berbuat apa-apa sedangkan setelah di berikan kebijakan otonomi daerah maka daerah

1 Syaukani, Otonomi Dalam Negara Kesatuan, Pustaka Pelajar, Cetakan IX, Yogyakarta, 2012. hlm. 9.

2 Jimly Asshidiqie, Konstitusi Dan Konstitusionalisme Indonesia, konstitusi press, Jakarta, 2010. hlm. 262-263. 
mendapatkan legitimasi untuk menjalankan sesuai dengan hak-haknya sesuai dengan kepentingan aspirasi daerah. Dengan adanya kebijakan otonomi daerah maka dianggap pemerintah lebih tahu kebutuhan masyarakat yang seluas-luasnya berdasarkan kepentingan dan aspirasi daerah tersebut. ${ }^{3}$ Dengan adanya perubahan sistem politik di Indonesia pasca reformasi maka dapat terlaksannya perubahan menuju sistem politik yang lebih demokratis, maka dengan adanya nilai-nilai sistem politik yang demokratis tersebut maka dapat mewujudkan paramaeter dalam mewujudkan keberhasilan untuk melaksanakan otonomi daerah yang efisien dan efektif serta bertanggung jawab. Dengan melibatkan rakyat dalam politik yang demokratis maka pemerintah pusat menerapkan sistem desentralisasi otonomi daerah kepada pemerintah daerah secara mandiri. ${ }^{4}$

Selain Undang-Undang Dasar yang mengatur pemerintah pusat dan pemerintahan daerah yang tugas serta kewenangannya dibatasi dalam pasal 18, pasal 18A, pasal 18B ayat 2 dijelaskan:

"Pemerintahan Daerah Provinsi, daerah kabupaten dan kota mengatur dan mengurus sendiri urusan pemerintahan menurut asas otonomi dan tugas pembantuan". Dan pada ayat 5 dijelaskan "pemerintahan daerah menjalankan otonomi seluas-luasnya kecuali urusan pemerintahan yang oleh undang-undang ditentukan sebagai urusan pemerintah pusat". Dan pada pasal 18 ayat 6 dijelaskan bahwa : "pemerintahan daerah berhak menetapkan peraturan daerah dan peraturan-peraturan lain untuk melaksanakan otonomi dan tugas pembantuan".

Dalam menjalankan otonomi daerah yang perlu untuk diperhatikan, daerah diberikan hak untuk menyusun sistem organisasi serta aturan kegiatan perangkat daerahnya. Adanya penyusunan membentuk perangkat daerah untuk menentukan suatu organisasi pemerintahan daerah telah terbagi atas prihal pilihan serta prihal wajib. Meskipun bahwa dalam penanganan setiap organisasi tersebut tidak harus di bentuk organisasi yang baru/tersendiri. Dengan dibentuknya organisasi struktur kelembagaan perangkat daerah maka diharapkan pemerintah daerah bisa menjalankan pemerintahan yang efisien dan efektif.

Pengertian perangkat daerah yaitu lembaga/organisasi pada pemerintahan daerah yang bertanggungjawab pada kepala daerah (Bupati,

\footnotetext{
${ }^{3}$ Suaib, "Pembentukan Dan Penataan Organisasi Perangkat Daerah" dalam 2 e Jurnal katalogis, Volume 5 Nomor 7 (2017). hlm.5

${ }^{4}$ Utang Rosidin, Otonomi Daerah Dan Desentralisasi, Pustaka Setia, Bandung, 2010. hlm. 50.
} 
Walikota, Gubernur) dan untuk membantu kepada kepala daerah dalam penyelenggaraan tugas pemerintahannya, berikutnya adalah yang dimaksud organisasi perangkat daerah yaitu organisasi yang ditetapkan oleh regulasi daerah berupa membentuk, mengabsahkan kedudukan, fungsi dan karya utama serta struktur instrumen organisasi sektor. ${ }^{5}$ Efisien dan efektif merupakan hal yang sangat diharapkan berkaitan dengan otonomi daerah karena hal tersebut menjadi cita-cita daerah yang ingin memajukan daerahnya sesuai dengan inovasi dan pengembangan kemampuan daerah tersebut untuk menggali potensi yang ada pada daerah tersebut dalam meningkatkan sumberdaya manusia dan penghasilan daerah yang lebih maju sesuai dengan pedoman Pancasila serta pandangan kebinekaan Indonesia. Efisien merupakan makna dari target tujuan akhir dari efektif.

Salah satu tujuan ditetapkannya peraturan Pemerintah daerah, salah satu aspek perubahan/pembaharuan tersebut terjadi pada masalah perangkat daerah dimana tugas perangkat daerah yaitu membantu kepala daerah (walikota, bupati, Gubernur) serta Dewan Perwakilan Daerah (DPRD) di dalam menyelenggarakan pemerintahan yang tercermin dalam Pasal 208, perubahan tersebut ditandai dengan menetapkan besarnya lembaga unit sektor dalam menjalankan kegiatan pemerintahan yang patut atau prefrensi dengan memperhatikan pertimbangan dari faktor-faktor jumlah penduduk, luas wilayah, jumlah pekerja serta kesiapan/kesanggupan keuangan daerah, dengan menetapkan besaran organisasi perangkat daerah dalam bentuk organisasi kedinasan/badan daerah.

Sehubungan adanya permasalah tersebut diatas, penulis akan melakukan kajian yang ditulis dalam bentuk penelitian ilmiah dengan Tema Konsep Ketatanegaraan Dalam Penataan Struktur Organisasi Perangkat Daerah Di Tinjau Dari Prinsip Efisien dan Efektif Menurut Undang-Undang Nomor 9 Tahun 2015 Tentang Perubahan Kedua Atas Undang-Undang Nomor 23 Tahun 2014 Tentang Pemerintahan Daerah.

\section{Rumusan Masalah}

Berasaskan latar belakang masalah sebagai halnya yang sudah dikemukakan diatas, lalu dapat dirumuskan pencarian masalah berikut ini Bagaimana sistem penataan struktur organisasi perangkat daerah menurut Undang-Undang Nomor 9 Tahun 2015 Tentang Perubahan Kedua Atas UndangUndang Nomor 23 Tahun 2014 Tentang Pemerintahan Daerah ? Bagaimana

\footnotetext{
${ }^{5}$ Haw. Widjaya, Penyelenggaraan Otonomi Daerah Di Indonesia, Raja Grafindo Persada,
} Jakarta, 2013. hlm. 12 . 
konsep penataan struktur organisasi perangkat daerah menurut UndangUndang Nomor 9 Tahun 2015 Tentang Perubahan Kedua Atas Undang-Undang Nomor 23 Tahun 2014 Tentang Pemerintahan Daerah mendukung terhadap terbentuknya tata kelola pemerintahan daerah yang efisien dan efektif ?

\section{Metode Penelitian}

Pengkajian disini memakai teknik strategi yuridis normatif, penulis melakukan kajian pendekatan perundang-undangan (Statute Aprrouch). ${ }^{6}$ Metode perundang-undangan yaitu mengggunakan legislasi dan kebijakan, dalam hal tersebut tidak saja Undang-Undang Tentang Peraturan Daerah, tetapi juga peraturan-peraturan yang melingkupinya. Selain menggunakan metode pendekatan Undang-Undang pada kajian ini penulis juga menggunakan metode pendekatan sejarah, pendekatan ini digunakan penulis agar dapat menjelaskan setiap konsep yang ada terutama konsep penataan struktur perangkat daerah, atau dilaksanakan pada konteks penyelidikan sejarah perangkat daerah melalui kurun waktu tertentu, disamping itu peneliti akan memahami tentang perubahan secara filosofis yang melandasi atau melatar belakangi aturan-aturan hukum tersebut. ${ }^{7}$

\section{Pembahasan}

Sistem Penataan Struktur Organisasi Perangkat Daerah Menurut UndangUndang Nomor 9 Tahun 2015 Tentang Perubahan Kedua Atas UndangUndang Nomor 23 Tahun 2014 Tentang Pemerintahan Daerah

Desentralisasi merupakan kebutuhan dan tututan masyarakat sejak lama dari angan-angan Negara demokrasi, banyak perdebatan yang dilakukan oleh Negara-negara berkaitan dengan konsep desentralisasi pada era sekitar tahun 1950. Pada tahun tersebut merupakan gelombang yang sangat dahsyat dalam konsep pertama desentralisasi menjadi perhatian khusus, dan bisa diartikan konsep yang sangat relevan pada waktu itu untuk memberdayakan dan memperkuat pemerintahan lokal. Dan pada periode kedua gelombang kedua konsep desentralisasi menguat perkembangan antar negara yang tengah berkembang sekitar antara tahun 1970an. ${ }^{8}$

Sejarah latar belakang munculnya konsep desentralisasi bermula pada konsep peningkatan pelayanan publik. Awal mula munculnya ide konsep

\footnotetext{
${ }^{6}$ Peter Mahmud Marzuki, Penelitian Hukum, Kencana Prenada, Jakarta, 2011. hlm. 96

${ }^{7}$ Ibid, hlm. 126.

${ }^{8}$ Syarif Hidayat at.all., Desentralisasi Dan Otonomi Daerah, Dalam Paradigma Baru Otonomi Daerah, P2P-LIPI, Jakrta: $2010 \mathrm{hlm}$. 22. Dikutip Kembali Oleh Juanda, Hukum Pemerintahan Daerah Pasang Surut Hubungan Kewenangan Antara DPRD Dan Kepala Daerah, Alumni, Bandung, 2013. hlm. 114.
} 
desentralisasi karena adanya upaya ingin meningkatkannya mutu layanan dibuat aparatur negara terhadap masyarakat sebagai warganya. Untuk melaksanakan tugas tersebut maka pemerintah menyerahkan pelayanan kepada lembaga yang dekat dengan masyarakat juga memberikan peran layanan publik kepada lembaga dibawahnya dan bisa juga dilakukan dengan pengalihan peran yang diberikan pada pelayanan publik untuk di suwastakan atau penyerahan dari pemerintah kepada swasta. ${ }^{9}$ Pengertian desentralisasi secara bahasa, menurut bahasa latin adalah De=lepas sedangkan sentralisasi berasal dari kata Centrum=Pusat dengan demikian desentralisasi dapat diartikan (pemerintahan daerah) yang menggugurkan sendiri dari pada (pemerintahan) sentral. Arti desentralisasi dalam konsep ketatanegaraan adalah pelimpahan/pemberian kekuasan yang diberikan oleh pusat pada daerah-daerah agar menyelenggarakan urusan rumah tangga masing-masing berdasarkan pada kemampuan masing-masing daerah. ${ }^{10}$

Menurut tinjauan sisi penyelenggaraan pemerintahan desentralisasi dapat diartikan "meringankan" kinerja pemerintah pusat. Adanya desentralisasi maka adanya peralihan tugas dan wewenang dari pusat kepada daerah. Maka pusat lebih memfokuskan dari prihal yang berkaitan pada kepentingan Negara bahkan nasional sebagai kedaulatan. ${ }^{11}$ Dapat disimpulakan bahwa konstruksi rumah tangga formal menunjukan urusan pemerintahan daerah adalah urusan sisa (residu) dan sewaktu-waktu dapat ditarik dan ditetapkan oleh pemerintah sebagai urusan pemerintah pusat, akibat yang mungkin muncul adalah menyimpan potensi sentralistik pada satu sisi dan sisi lainnya kemungkinan akan menekan kratifitas daerah untuk mengembangkan potensi-potensi yang dikelolanya.

Matinya kreatifitas disebabkan oleh kemungkinan suatu urusan yang dikelola dan dikembangkan daerah berpeluang ditarik untuk sentral pemerintahan.faham rumah tangga ini mengakui adanya urusan pemerintah yang berbeda kewenangan antara pemerintahan pusat dan daerah. Dengan adanya perbedaan urusan tersebut oleh karena memang keduanya memiliki materi dan ruang lingkup yang berbeda. ${ }^{12}$ Pendekatan rumah tangga materil yang meyakini adanya perbedaan antara urusan pemerintahan pusat dan pemerintahan daerah menyebabkan adanya uraian, batasan, lebih rinci dan lebih tegas. Terkait urusan yang menjadi wewenang membentuk wilayah

\footnotetext{
9 Laode Ida, “Desentralisasi Dan Demokrasi”, Demokrasi Dan HAM, September 2012. hlm. 97.

${ }^{10}$ Viktor M. Situmorang, Hukum Administrasi Pemerintahan Di Daerah, Sinar Grafika, Jakarta, 2011. hlm. 38.

${ }^{11}$ Bagir Manan, Perjalanan Historis, Op Cit, hlm. 62-63.

${ }^{12} \mathrm{lbid}, \mathrm{hlm}, 28$.
} 
otonomi. ${ }^{13}$ Sistem rumah tangga ini disebut sebagai sistem otonomi nyata atau bisa juga dikatakan otonomi riil. Mengapa disebut nyata, karena didasarkan pada keadaan-keadaan dan faktor-faktor yang nyata, sistem ini dikatakan sebagai jalan tengah. Dan yang dimaksud dengan jalan tengah adalah jalan tengah antara sistem rumah tangga formal dengan sistem rumah tangga material. Wewenang yang dirumuskan secara umum pada sistem rumah tangga formal memberikan landasan untuk mewujudkan prinsip kebebasan dan kemandirian. Sedangkan kelemahan sistem rumah tangga material akan merangsang timbulnya ketidakpuasan daerah dan spanning hubungan antara pusat dan daerah.

Menurut ajaran sistem ini, menentukan terlebih dahulu kaitan antara tugas-tugas yang menjadi kewenangan pusat, sedangkan bagi kewenangan-kewenangan daerah yaitu sisanya. Dan keutamaan sistem ini adalah terletak pada keperluan-keperluan baru. Maka daerah diminta untuk cepat mengambil tindakan dalam pengambilan keputusan yang strategis tanpa harus menunggu instruksi dari pusat. Dan kelemahan dalam system ini adanya kesulitan karena kemampuan yang tidak sama antara daerah satu dengan daerah lainnya dari bernbagai hal dan dan bidang-bidang tertentu. Sehingga mengakibatkan tugas-tugas dan bidang-bidang yang telah dirumuskan secara umum menjadi sempit bagi yang mempunyai kapasitas besar dan bisa menjadi sebaliknya terlalu luas bagi daerah yang mempunyai kemampuan keterbatasan. ${ }^{14}$

Prinsip ini bagian dari variasi system otonomi riil. Otonomi itu merupakan hak yang telah diberikan oleh Negara melalui undang-undang dalam pelaksanaannya harus dipertanggungjawabkan, dan pada intinya dalam pelaksanaannya harus sesuai dengan tujuan otonomi tersebut, yaitu yang merealisasikan kinerja pembangunan sampai keseluruh ploksok negeri sesuai dengan kaidah perundang-undangan. Kecocokan tersebut bisa dibuktikan melalui antara rakyat dengan kepala daerah serta serasi dalam urusan dengan pemerintahan pusat, dan juga pusat dan daerah, serta dapat menjamin perkembangan dan pembangunan daerah.

Menurut istilah "Pemerintahan" dalam bahasa inggris "governance" adalah "the act, fact, manner of governing" yang berati "tindakan, fakta, pola, dan kegiatan atau penyelenggaraan pemerintahan". Jadi istilah "governance" merupakan (proses) suatu kegiatan bahwa governance lebih merupakan “.....serangkaian proses interaksi sosial politik antara

\footnotetext{
${ }^{13}$ Koswara E, Otonomi Daerah Untuk Demokrasi Dan Kemandirian Rakyat, Serambi Aksara Nusantara, Jakarta, 2010. hlm. 78.

${ }^{14}$ Josef Riwu Kaho, Prospek Otonomi Daerah Di Negara Republik Indonesia, Rajawali pers, Jakarta, 2010. hlm. 17
} 
pemerintahan dengan masyarakat dalam berbagai bidang yang berkaitan dengan kepentingan masyarakat dan intervensi pemerintah atas kepentingankepentingan tersebut". Secara istilih "good governance" banyak ditemukan dengan pengertian "pengelolaan yang baik/penyelenggaraan yang baik". ${ }^{15}$ Prinsip-prinsip pemerintahan yang baik pada dasarnya mengandung nilai yang rasional dan objektif, apabila diterapkan sistem ini dengan baik maka bisa menjadi tolak ukur, indikator, dan ciri-ciri karakteristiknya pemerintahan yang baik maka dapat diterapkan pada suatu daerah. Dalam mewujudkan good governance adalah pelaksanaan penyelenggaraan pemerintahan Negara yang bertanggung jawab, solid, efisien dan efektif.

\section{Sistem Penataan Struktur Organisasi Perangkat Daerah Ditinjau Dari Prinsip Efisien Dan Efektif}

Pada Tahun 2014 Pemerintah Indonesia menetapkan Undang-Undang Pemerintahan Daerah hal ini dilakukan dalam rangka penyempurnaan dan penyesuaian keadaan perkembangan ketatanegaraan, penyelenggaraan pemerintah daerah yang lebih baik. Otonomi daerah sesuai perundangundangan membentuk wilayah menjadi tiga bagian yaitu Daerah Provinsi, Daerah Kabupaten/Kota, dan Desa/Kelurahan. Provinsi dibagi menjadi Kabupaten dan Kota kemudian Kabupaten dan Kota dibagi menjadi kecamatan lalu kecamatan dibagi lagi menjadi Kelurahan/Desa.

Menurut pembagian urusan pemerintahan sebagaimana telah diatur dalam pasal 13 ayat (1) Dalam Undang-Undang Pemerintahan Daerah, yang menyatakan bahwa: Dalam urusan pembagian otonomi pemerintahan konkuren itu terbagi antara urusan pusat dengan daerah. Sedangkan daerah sendiri terbagi lagi menjadi provinsi dan kabupaten/kota maka hal tersebut bisa dilaksanakan pembagian secara otonomi sedangkan dalam pelaksanaan otonomi tersebut harus disandarkan pada nilai-nilai prinsip Akuntabilitas, Efisiensi, dan Eksternalitas serta kepentingan strategis nasional. Dan yang dimaksud dengan "Prinsip efisiensi" adalah ketentuan penyelenggaraan urusan pemerintahan ditentukan berdasarkan perbandingan tingkat daya guna yang paling tinggi yang dapat diperoleh. Sedangkan "Prinsip Efektifitas" sejauh mana penyelenggaraan pemerintahan tersebut dapat tercapai/terlaksana.

Organisasi adalah suatu kelompok atau unit yang terdiri dari orang yang berinteraksi satu sama lain yang mempunyai tujuan yang sama. Menurut Winardi, dalam bukunya Manajemen Perilaku Organisasi, menentukan prinsip-

15 Sedarmayanti, Manajemen Sumber Daya Manusia Reformasi Birokrasi Dan Manajemen Pegawai Negeri Sipil, PT Refka Aditama, Bandung, 2015. hlm. 141. 
prinsip struktur organiasasi sebagai berikut: ${ }^{16}$ Pembagian Kerja dan Spesialisasi; Garis-garis Otoritas yang Jelas; Penetapan Tanggung jawab secara Jelas; Kemampuan sesuai dengan tanggungjawab; Kesatuan atau kesesuaian penugasan fungsi-fungsi serupa yang berhubungan erat dalam struktur yang ada; Rentang pengawasan terdapat adanya pembatasan jumlah bawahan yang dapat disupervisi oleh atasan; Komunikasi semua unit dan individu-individu dalam organisasi yang tanggungjawab mereka dapat melaksanakan tanpa batasan-batasan dari struktur formal; Komite-komite yang dibentuk dengan baik merupakan alat administrasi yang berharga.

Terdapat beberapa jenis struktur organisasi yaitu: (1) struktur lini, (2) struktur lini dan staf, (3) struktur fungsional, (4) struktur lini dan fungsional, (5) struktur lini, staf dan fungsional, (6) struktur sederhana, (7) struktur birokrasi mekanistik, (8) struktur birokrasi professional (9) struktur divisional, (10) struktur adhcory, (11) struktur missionaries. ${ }^{17}$ Pendapat Markus zahnd pada bukunya yang berjudul "Perancangan Kota Secara Terpadu" mengartikan makna efisien dan efektifitas yaitu: "efisien berarti tepat atau sesuai untuk mengerjakan sesuatu dengan tidak membuang-buang waktu, tenaga dan biaya, sedangkan Efektifitas yaitu berfokus pada akibatnya, pengaruhnya atau efeknya". 18

Penataan struktur organisasi Perangkat Daerah menurut perundanguandangan melalui pembagian perangkat daerah yang terdiri dari perangkat daerah Provinsi dan perangkat daerah Kabupaten/kota dimana pembentukan dan susunan perangkat daerah ditetapkan dengan peraturan daerah atas dasar persetujuan menteri. Perangkat daerah Provinsi terdiri atas: Sekretariat Daerah, Sekretariat DPRD, Inspektorat, Dinas, Badan. Sedangkan perangkat daerah kabupaten/kota terdiri atas: Sekretariat Daerah, Sekretariat DPRD, Inspektorat, Dinas, Badan, dan Kecamatan.

Dalam penelitian ini menurut penulis menganggap belum dapat memenuhi prinsip efektif dan efisien penyelenggaraan pemerintahan (good governance), hal ini dibuktikan dengan masih adanya pengaturan tentang organisasi perangkat daerah yang belum mencapai konsep efisien dan efektif, efisien cenderung pada penggunaan sumber daya dalam pencapaian tujuan, sedangkan efektif menekankan pada hasil atau efeknya dalam pencapaian tujuan dengan besaran design struktur yang tepat, berdasarkan hal tersebut, bahwa efektif mempunyai hubungan timbal balik antara output

${ }^{16}$ Winardi, Manajemen Prilaku Organisasi, Kencana, Bandung, 2014. hlm. 189-190.

17 Lembaga Administrasi Negara, Penataan Organisasi Pemerintah: Konsep Dan Praktek, LAN Deputi Bidang Kajian Kinerja Kelembagaan Dan Sumber Daya Aparatur, Jakarta, 2011. hlm. 31.

${ }^{18}$ Markus Zahnd, Perancangan Kota Secara Terpadu, Kanisius, Yogyakarta, 2016. hlm. 200 
dengan tujuan. Semakin besar kontribusi output maka semakin efektif suatu program atau kegiatan tersebut. Berarti, bahwa efektif yang dipentingkan adalah semata-mata hasil atau tujuan yang dikehendaki.

\section{Penutup}

\section{Simpulan}

Pada hakekatnya sistem penataan organisasi perangkat daerah berdasarkan Perundang-undangan tentang pemerintahan daerah berangkat dari desentralisasi berdasarkan asas otonomi daerah yang diberikan kepada rakyat sebagai satu kesatuan masyarakat hukum dan perundangundangan telah memberikan kewenangan kepada daerah untuk mengatur rumah tangganya sendiri aturan tersebut dibuat dan diberikan oleh pusat kepada daerah untuk dilaksanakan berdasarkan prinsip otonomi. Dalam menjalankan pelaksanaannya dilakukan oleh Kepala Daerah yang bertanggung jawab dan Dewan Perwakilan Rakyat Daerah (DPRD) serta dibantu oleh perangkat daerah lainnya. Penataan struktur organisasi seharusnya tidak boleh lepas dari pendekatan "tepat fungsi dan tepat ukuran" (rightsizing) artinya organisasi yang dibentuk memiliki ukuran yang tepat dengan memiliki fungsi yang tepat pula. Artinya Organisasi terlalu besar dapat mengakibatkan ketidakefisienan dikarenakan kurang tepat sasaran dan tujuannya. Dalam upaya peningkatan efektifitas juga dapat dilakukan dengan cara restrukturisasi organisasi dengan tujuan untuk kepentingan menjalankan fungsi-fungsi organisasi daerah serta dapat melaksanakan tugas-tugas pokok dari setiap organisasi daerah tersebut. Melalui pelaksanaan penataan kelembagaan organisasi tersebut harapannya adalah fungsi pemerintah daerah agar bisa lebih efektif dan efisien. Melalui Konsepdesain struktur organisasi perangkat daerah jenis struktur fungsional struktur fungsional berupa kelompok ahli, gugus tugas (task force).

\section{Saran}

Kepada perangkat pemerintahan daerah harusnya dibuat dengan struktur yang efektif dan efisien sesuai dengan tugas dan fungsi setiap struktur yang ada dalam kelembagaan, setiap bagian diharuskan kaya fungsi bukan kaya struktur namun tidak kongkit hasil dari tugas dan fungsinya. Efesiensi penting untuk dilakukan karena menyesuaikan dengan anggaran daerah yang dibebankan terhadap fungsional kelembagaan. Idealnya struktur harus kaya fungsi dan hasil yang kongrit sehingga berjalan efektif dan efisien. 


\section{Daftar Pustaka}

Buku

Bagir Manan, Perjalanan Historis Pasal 18 UUD 1945, UNISKA, Jakarta, 2010. Haw.Widjaya, Penyelenggraan Otonomi Daerah Di Indonesia, Raja Grafindo Persada,Jakarta, 2013.

Jimly Asshidiqie, Konstitusi Dan Konstitusionalisme Indonesia, Konstitusi Press, Jakarta, 2010.

Josef Riwu Kaho, Prospek Otonomi Daerah Di Negara Republik Indonesia, Edisi 1 cet ke-1, Rajawali Pers, Jakarta, 2010.

Koswara E, Otonomi Daerah Untuk Demokrasi Dan Kemandirian Rakyat, Serambi Aksara Nusantara, Jakarta, 2010.

Markus Zahnd, Perancangan Kota Secara Terpadu, Kanisius, Yogyakarta, 2016. Peter Mahmud Marzuki, Penelitian Hukum, Kencana Prenada, Jakarta, 2011. Sedarmayanti, Manajemen Sumber Daya Manusia Reformasi Birokrasi Dan Manajemen Pegawai Negeri Sipil, PT Refka Aditama, Bandung, 2015.

Syaukani H.R. at.all., Otonomi Daerah Dalam Negara Kesatuan, Cet ke-IX,

Pustaka Pelajar, Yogyakarta, 2012.

Utang Rosidin, Otonomi Daerah Dan Desentralisasi, Pustaka Setia, Bandung, 2010.

Viktor M. Situmorang, Hukum Administrasi Pemerintahan Di Daerah, Sinar Grafika, Jakarta, 2011.

Winardi, Manajemen Perilaku Organisasi, Kencana, Bandung, 2014.

Jurnal

Laode Ida. "Desentralisasi dan Demokrasi”, Demokrasi dan HAM, (2012)

Laili Fadhilah, Nurul. "Implikasi Pemberlakuan Undang-Undang No. 9 Tahun 2015 Tentang Perubahan Kedua Undang-Undang No. 23 Tahun 2014 Tentang Pemerintah Daerah Atas Perizinan Pertambangan Terhadap Legislasi Di Daerah" dalam Jurnal Ilmiah Pendidikan

Pancasila Dan Kewarganegaraan, Th. 1 Nomor. 2 (2016)

LAN-BPKP, Akuntabilitas Dan Good Governance, Jakarta: LNRI, (2011).

Lembaga Administrasi Negara, Penataan Organisasi Pemerintah : Konsep dan

Praktek, Jakarta: LAN Deputi Bidang Kajian Kinerja Kelembagaan Dan

Sumberdaya Aparatur, (2011)

Suaib, "Pembentukan Dan Penataan Organisasi Perangkat Daerah" dalam 2 e Jurnal katalogis, Volume 5 Nomor 7 (2017)

Sulton, Dedi, Yusi. “Analisis Penataan Daerah Di Provinsi Jawa Barat” dalam

Transformasi:Jurnal Manajemen Pemerintahan/vol. 9 No. 1 (2017) 
Syarif Hidayat, Bhenyamin Hoessein. Desentralisasi Dan Otonomi Daerah, Dalam Paradigma Baru Otonomi Daerah, P2P-LIPI, (2010). Dikutip kembali oleh

Juanda, Hukum Pemerintahan Daerah Pasang Surut Hubungan Kewenangan antara DPRD dan Kepala Daerah, Alumni, Bandung, (2013).

Rasyid Thaha. "Penataan Kelembagaan Pemerintahan Daerah" dalam Government: Jurnal Ilmu Pemerintahan vol.2 no.1 (2012)

Rachmi Yuliyanti. "Reformasi Tata Kelola Pemerintahan Desa Melalui Penataan Kelembagaan” dalam Jurnal SAWALA vol.6 No.1 (2018)

\section{Peraturan Perundang-Undangan}

Undang-Undang Negara Republik Indonesia Tahun 1945

Undang-Undang Nomor 22 Tahun 1999 Tentang Pemerintahan Daerah

Undang-Undang Nomor 32 Tahun 2004 Tentang Pemerintahan Daerah

Undang-Undang Nomor 9 Tahun 2015 Tentang Perubahan Kedua Atas UndangUndang Nomor 23 Tahun 2014 Tentang Pemerintahan Daerah 